\title{
LIGHT AND DARK CELLS IN THE LUMBAR SENSORY GANGLIA OF PRE AND POST-HATCHING DOMESTIC FOWL
}

\author{
CLAUDIO A. FERRAZ DE CARVALHO*-CIRO F. DA SILVA**
}

SUMMARY - Clear and dark satellite cell classes were identified by electron microscopy in the lumbar sensory ganglia of domestic fowl in 8 pre and 4 post-hatching stages of development. Some cytologic differences found between the two classes relating to the rough-endoplasmic reticulum, ribosomes, Golgi apparatus and junctional complexes suggest. the existence of distinct functional features for both types of satellite cells.

Células satélítes claras e escuras em gânglios sensitivos lombares de Gallus demesticus antes e depois da eclosão.

RESUMO - Foram identificadas, por microscopia eletrônica, células satélites claras e escuras em gânglios sensitivos lombares do galo doméstico, em 8 fases pré e 4 fases pós-eclosão. Algumas diferenças citológicas encontradas, referentes ao retículo endoplasmático rugoso, ribosomos, aparelho de Golgi e complexos juncionais, sugerem a existência de caracteristicas funcionais distintas para ambos os tipos de células satélites.

Large light and small dark sensory ganglion neurons (A and B cells respectively) were described by Scharf 5 and Andres 1 . According to Cammermeyer 2 there is good evidence that at least some types of dark cells are avoidable artefacts of tissue preparation. Nevertheless, many authors have found consistent ultrastructural, radioautographic and histochemical differences between these cells (for a review see Lieberman 4 ), probably related to distinct functional features.

In this paper we describe the presence of dark and light satellite cells in the lumbar spinal ganglia of the chicken in 12 different pre- and post-hatching stages.

\section{MATERIAL AND METHODS}

Four lumbar sensory ganglia of chick embryos from the 5th, 7th, 8th, 10th, 14th, 16th, 18th and 20th incubation days and of $8,36,61$ and 120 days old chickens were studied. Three specimens were used for each phase. Fragments were removed and fixed in $2 \%$ glutaraldehyde buffered with $0.1 \mathrm{M}$ sodium cacodylate (pH $7.2,480 \mathrm{mOs}$ ) at $4 \circ \mathrm{C}$ for $2 \mathrm{hr}$ and post-fixed in $1 \%$ OsO4 in $0.65 \mathrm{M}$ phosphate buffer (with $123 \mathrm{mg} / \mathrm{ml}$ sucrose) at the same temperature. After a quick rinse in phosphate buffer the fragments were dehydrated in ethanol-propylene oxide and embebed in Araldite. Thin sections were stained with lead citrate and uranil acetate and analysed in a Phillips EM-201 electron microscope of the Heart Institute of the são Paulo Medical School.

\section{RESULTS}

Two kinds of satellite cells (clear and dark cells) could be distinguished on the basis of very marked differences in the electron density of their hyaloplasm. These cell types

This work was performed in the Department of Anatomy, Institute of Biomedical Science, University of Săo Paulo (* Full Professor; ** Assistant Professor) and supported by a grant from FAPESP (PB-86/3336-0) to C.A.F.C.

Departumento de Anatomia, Instituto de Ciências Biomedicas Universidade de Säo Paulo Caixa Postal 4.365 - 01051 - Säo Paulo, SP - Bnasil. 
were evident from the 15 th incubation day on and were quite numerous from the 35 th to the 120th post-hatching days. Both cell types could be scen envelopping the same neuronal perikaryon and no apparent relation of these cells with light and dark neurons could be detected (Figs. 1 to 5 ).

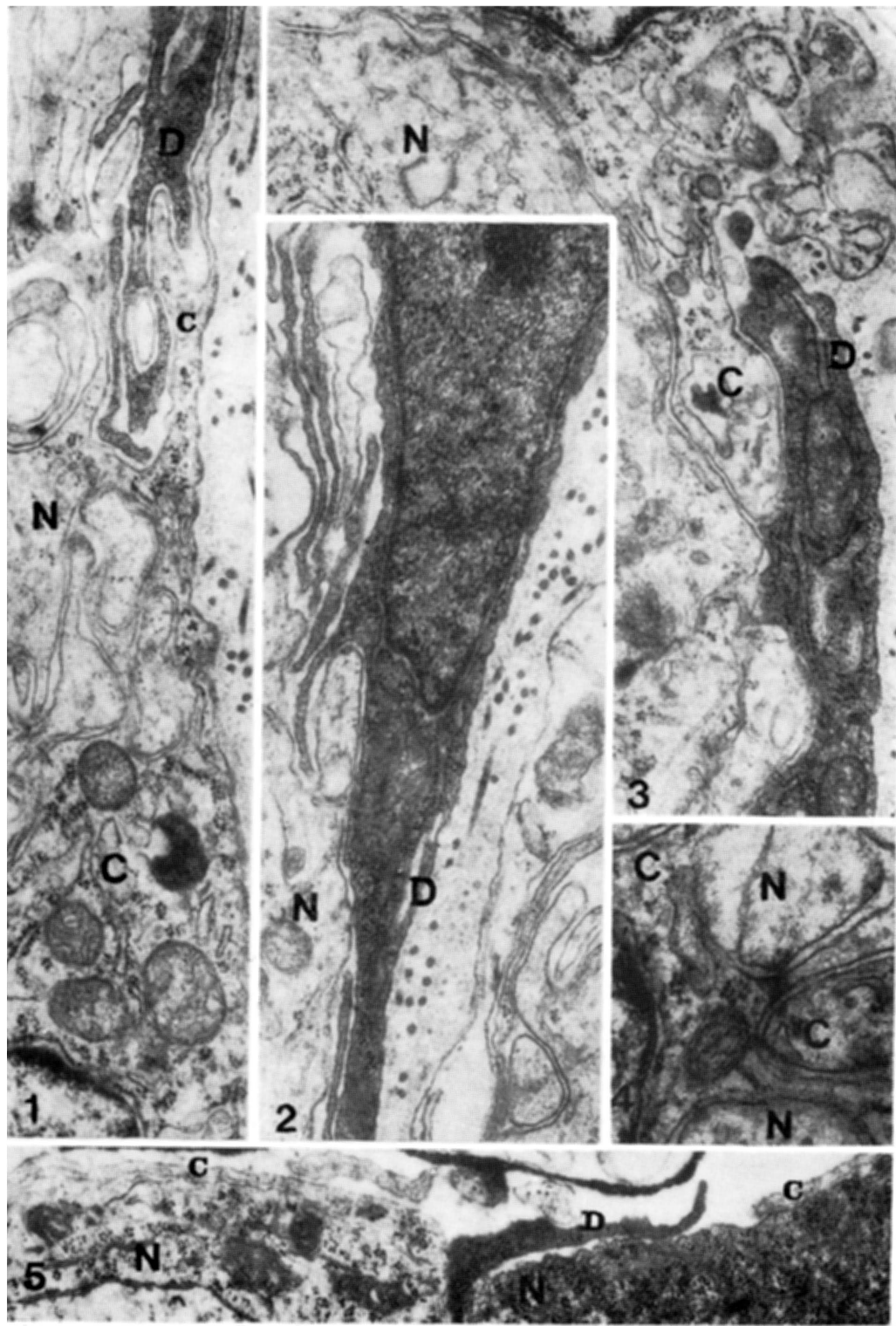

Figs. 1-5 - Electron micrographs of satellite cells of lumbar sensory ganglia of domestic fowl. $C$, clear cell; $D$, dark cell; $N$, nerve cell. Figs. 1 to 4 correspond to specimens on the 61 st day; Fig. 5 correspond to a 35th day specimen. (Figs. 1,2,3 $\times 33750 ;$ Fig. $4 \times 57000$; Fig. $5 \times 19000$ ). 
The dark satellite cells were smaller and with thinner laminar evaginations than the clear ones (Figs. 1 and 2). Ribosomes were more numerous and scattered in the dark cells even in the smallest processes (Figs. 1 and 5); in the clear cells they tended to form clusters (Fig. 3). The rough-endoplasmic reticulum (RER) showed more numerous membrane-attached ribosomes in the dark cells compared to the clear cells, in which the cisterns of the RER were more or less extensively devoided of associated ribosomes (Figs. 1 and 3 ). The RER content was also more electron dense in the dark cells (Fig. 3). In these cells the Golgi complex was poorly developed and the smooth-endoplasmic reticulum was rarely observed. Furthermore, the dark cells seemed to be related more loosely with their neighboring satellite and neuronal cells (Fig. 2). Small adhering and thight junctions were observed at the ultrastructural level between the laminar expansions of the clear satellite cells (Fig. 4) and only adhering junctions were found between these expansions and the plasma membrane of the neurons, which was not the case tor the dark cells. In both cell types microfilaments and microtubules were relatively rare.

\section{COMMENTS}

Although clear and dark nerve cells were extensively studied in sensory ganglia 4 , similar considerations have not been made in relation to the satellite cells.

Differences in electron density were also described for cells in other tissues, c.g. the pancreatic acinar cells 3 , and were always either related to artefactual procedures or functional differences.

The ultrastructural differences between clear and dark cells described here support the idea of distinct functional modalities for the satellite cells of the sensory ganglia.

\section{REFERENCES}

1. Andres $\mathbf{K H}-$ Untersuchungen ueber den Feinbaun von Spinal ganglien. $z$ Zellforsoh $55: 1,1961$.

2. Cammermeyer $J$ - An evaluation of the significance of the «dark» neuron. Erg Anat Entw 36:1, 1962.

3. Ekholm R, Edlund $\mathbf{Y}$ - Ultrastructure of the human exocrine pancreas. J Ultrastruct Res $2: 453,1959$.

4. Lieberman AR - Sensory ganglia. In Landon DN (ed): The Peripheral Nerve. John Wiley \& Sons, New York, 1976.

5. Scharf $\mathrm{J}-\mathrm{H}$ - Sensible ganglien. In Handbuch der mikroskopischen Anatomie des Menschen. Vol IV/3 Nerven system III. Springer, Berlin, 1958. 